\title{
Perbandingan instalasi penerangan terhadap konsumsi daya di area line maintenance bandara
}

\section{Gede Suputra Widharma1, I Nengah Sunaya²}

1. Politeknik Negeri Bali, Indonesia | geddsuputra@pnb.ac.id

2. Politeknik Negeri Bali, Indonesia | nengahsunaya@pnb.ac.id

\begin{abstract}
Abstrak
Perbandingan instalasi penerangan dengan menggunakan lampu pijar, lampu bohlam dan lampu LED (Light Emitting Diode) di area line maintenance bandara. Lampu memiliki konsumsi daya dan intensitas cahaya yang berbeda. Hasil perhitungan konsumsi daya dengan menggunakan formula yang sesuai serta mengukur intensitas cahaya masing-masing lampu tersebut. Dari perhitungan yang dilakukan, lampu LED memiliki konsumsi daya yang lebih hemat serta intensitas cahaya yang lebih baik ketimbang lampu yang lain. Sehingga pemakaian lampu LED lebih baik untuk menggantikan peran lampu bohlam. Penelitian ini dilakukan dalam penentuan jumlah lampu yang akan digunakan untuk penerangan pada instalasi lampu di Area Line Maintenance Bandara..
\end{abstract}

\section{Kata Kunci}

Instalasi, lampu, daya, intensitas

TEKNO Vol. 29 Issue 1, p1-12 | Jurusan Teknik Elektro, Universitas Negeri Malang, Indonesia | Maret 2019

I.G.S Widharma, I.N. Sunaya | Perbandingan instalasi penerangan terhadap konsumsi daya di area line maintenance bandara ... 


\section{TEKNO Jumal Teknologi Eektro dan Kejuruon}

http://journal2.um.ac.id/index.php/tekno | ISSN 1693-8739

\section{Pendahuluan}

Bola lampu terus berkembang sejak ditemukan hampir dua abad silam. Tuntutan hemat energi memicu inovasi untuk menghasilkan lampu yang efisien dalam memanfaatkan energi (Suputra, 2012). Thomas Alva Edison, Amerika Serikat, pada 1870-an menghasilkan bola lampu pijar. Cahaya lampu pijar berasal dari nyala filamen, kawat tipis dari tungsten. Saat lampu dinyalakan, arus listrik memanaskan filamen hingga suhu 2.200 derajat celsius (Muhaimin, 2001) hingga filamen berpijar (Amaulah, 2002). Supaya panas terkonsentrasi di sekitar filamen, tungsten ditempatkan dalam bola lampu kedap udara. Sifat boros lampu pijar mendorong ilmuwan dan perekayasa mencari bola lampu baru lebih efisien terkait energi. Lahirlah lampu pendar atau lampu fluorosensi pada 1938. Lampu ini paling banyak digunakan di Indonesia, baik tabung (tubular lamp/TL) maupun kompak atau sebagian masyarakat menyebutnya lampu neon .

Meski lebih hemat dari lampu pijar, keberadaan merkuri yang merupakan logam berat dalam lampu pendar jadi masalah baru karena merusak lingkungan dan mengganggu kesehatan. Tuntutan untuk lampu yang semakin hemat dan bisa diaplikasikan lebih luas melahirkan lampu berteknologi dioda pemancar cahaya (light-emitting diode/LED). Penelitian lampu LED dimulai 1960-an dengan menghasilkan lampu LED merah dan hijau, kemudian pada 1990-an, LED biru hadir. Dengan temuan LED biru, LED putih bisa dibuat.

\section{Metode}

\subsection{Rancangan Penelitian}

Dalam pengumpulan data untuk menyelesaikan penelitian ini dilakukan pengamatan langsung terhadap iinstalasi lampu penerangan di line area maintenance bandara internasionall ngurah rai. Sebelumnya akan dihitung perbandingan penggunaan daya dan masing masing intensitas cahaya dari lampu yang akan digunakan.

Dengan begitu banyaknya kelebihan yang dimiliki lampu jenis LED (light emiting diode) dibandingkan jenis lampu lainnya ,penggunaan daya yang lebih kecil lagi dapat menjadikan lampu ini sangat tepat digunakan untuk mengurangi pemborosan pemakaian daya pada lampu jenis lain (Suryatmo, 1993).

\subsection{Landasan Teori}

\subsubsection{Lampu Pijar}

Jenis lampu yang dikembangkan Thomas Alfa Edison ini memakai filamen tungsten yaitu semacam kawat pijar didalam bola kaca yang diisi gas nitrogen, argon, kripton, hidrogen dan sebagainya. Lampu ini membutuhkan lebih banyak energi dibandingkan lampu TL untuk

TEKNO Vol. 29 Issue 1, p1-12 | Jurusan Teknik Elektro, Universitas Negeri Malang, Indonesia | Maret 2019

I.G.S Widharma, I.N. Sunaya | Perbandingan instalasi penerangan terhadap konsumsi daya di area line maintenance bandara ... 


\section{TEKNO Junal Teknologi Elektro dan Kejurvon}

http://journal2.um.ac.id/index.php/tekno | ISSN 1693-8739

mendapatkan tingkat terang yang sama. Lampu pijar atau bohlam biasa ini hanya bertahan 1000 jam atau untuk rata-rata pemakaian 10 jam sehari semalam, hanya bertahan kira-kira 3 - 4 bulan, dan setelah itu kita harus membeli bohlam baru.

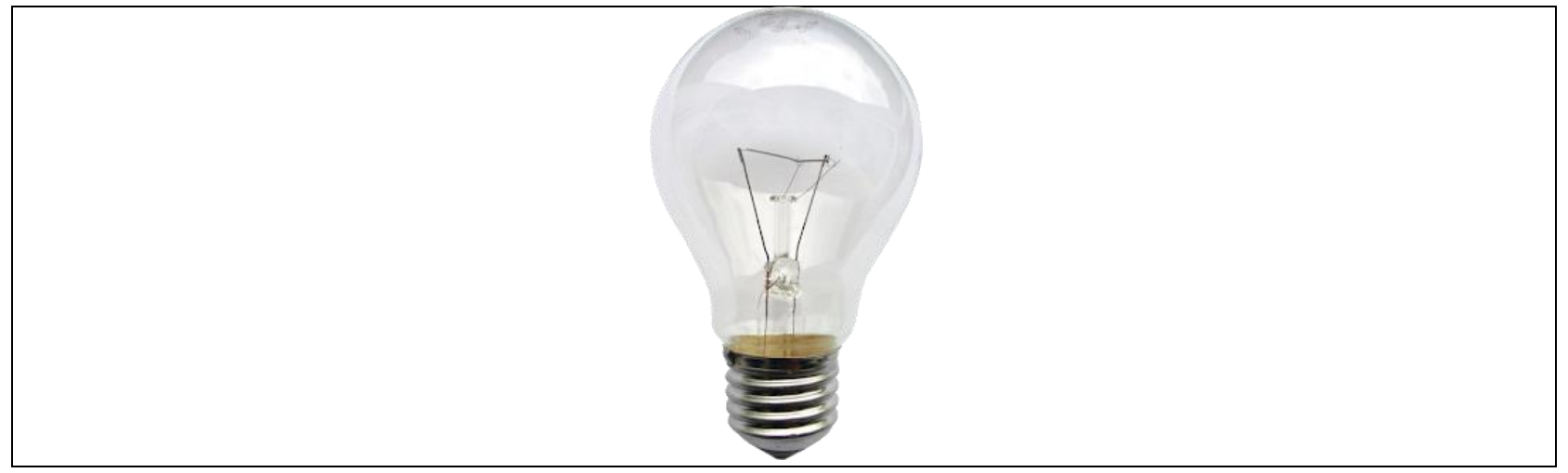

Gambar 1. Lampu Pijar

\subsubsection{Lampu PT}

Jenis lampu ini juga dikenal dengan lampu neon. Dewasa ini lampu neon bentuknya macammacam, ada yang bentuknya memanjang biasa, bentuk spiral atau tornado, dan ada juga yang bentuk memanjang vertikal dengan fitting (bentuk pemasangan ke kap lampu) yang mirip seperti lampu pijar biasa. Lampu TL lebih hemat energi dibandingkan lampu pijar, karena lebih terang. Untuk lampu TL yang baik (merk bagus), bisa bertahan 15.000 jam atau setara dengan 10 tahun pemakaian, harganya juga sekitar 10x lampu pijar biasa.

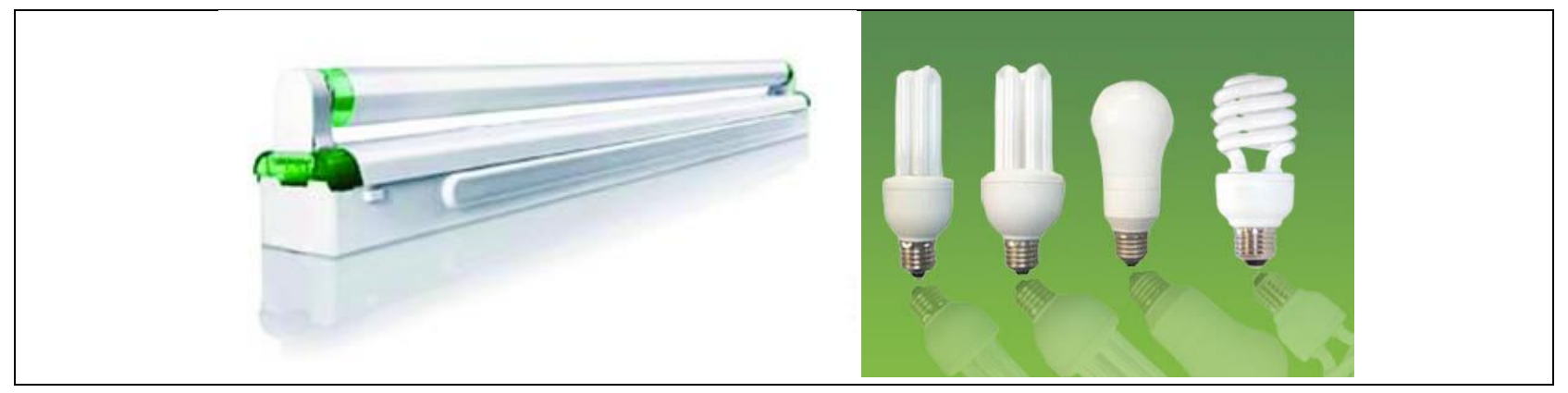

Gambar 2. Lampu TL

\subsubsection{Lampu Halogen}

Lampu halogen biasanya memiliki reflektor (cermin dibelakangnya) untuk memperkuat cahaya yang keluar. Fittingnya biasanya khusus, namun saat ini ada pula yang dengan jenis fitting biasa. 


\section{TEKNO Junal Teknologi Elekro dan Kejuruan}

http://journal2.um.ac.id/index.php/tekno | ISSN 1693-8739

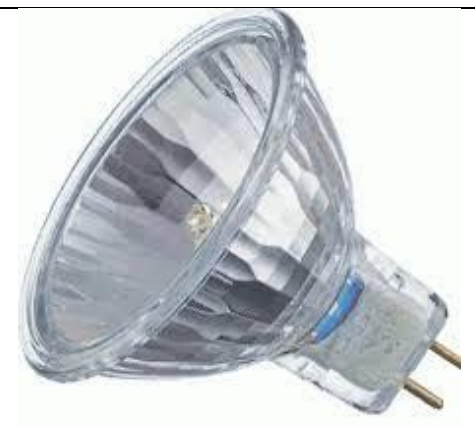

Gambar 3. Lampu Halogen

Lampu jenis ini merupakan lampu spot yang baik. Lampu spot adalah lampu yang cahayanya mengarah ke satu area saja, misalnya lampu untuk menerangi benda seni secara terfokus. Lampu ini baik untuk digunakan sebagai penerangan taman untuk membuat kesan dramatis dari pencahayaan terpusat seperti menerangi patung, tanaman, kolam atau area lainnya. Jenis lampu ini sebenarnya merupakan lampu filamen yang sudah berhasil dikembangkan menjadi lebih terang, namun juga kebutuhan energi (watt) yang relatif sama.

\subsubsection{Lampu LED}

Lampu ini merupakan sirkuit semikonduktor yang memancarkan cahaya ketika dialiri listrik. Sifatnya berbeda dengan filamen yang harus dipijarkan (dibakar) atau lampu TL yang merupakan pijaran partikel. Lampu LED memancarkan cahaya lewat aliran listrik yang relatif tidak menghasilkan banyak panas. Karena itu lampu LED terasa dingin dipakai karena tidak menambah panas ruangan seperti lampu pijar. Lampu LED juga memiliki warna sinar yang beragam, yaitu putih, kuning, dan warna-warna lainnya.

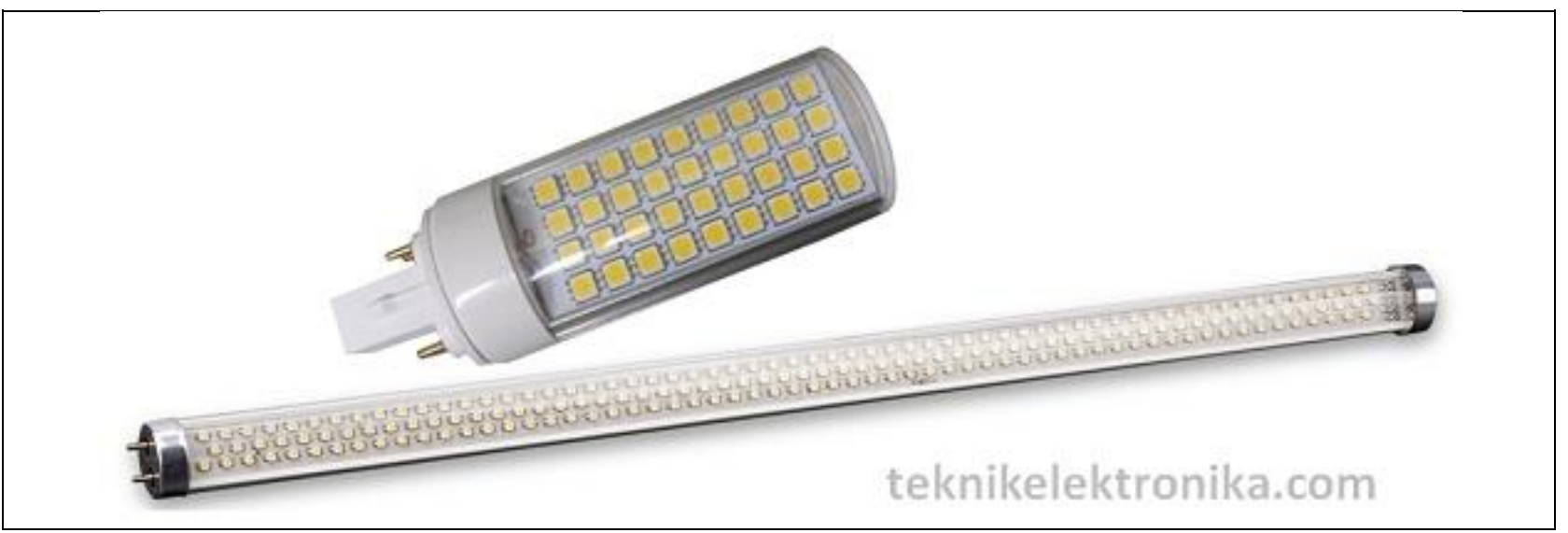

Gambar 4. Lampu LED

TEKNO Vol. 29 Issue 1, p1-12 | Jurusan Teknik Elektro, Universitas Negeri Malang, Indonesia | Maret 2019

I.G.S Widharma, I.N. Sunaya | Perbandingan instalasi penerangan terhadap konsumsi daya di area line maintenance bandara ... 


\section{TEKNO Jumal Teknologi Eektro dan Kejuruan}

http://journal2.um.ac.id/index.php/tekno | ISSN 1693-8739

\section{Hasil}

\subsection{LED (Light Emitting Diode)}

Light Emitting Diode atau sering disingkat dengan LED adalah komponen elektronika yang dapat memancarkan cahaya monokromatik ketika diberikan tegangan maju. LED merupakan keluarga Dioda yang terbuat dari bahan semikonduktor. Warna-warna Cahaya yang dipancarkan oleh LED tergantung pada jenis bahan semikonduktor yang dipergunakannya. LED juga dapat memancarkan sinar inframerah yang tidak tampak oleh mata seperti yang sering kita jumpai pada Remote Control TV ataupun Remote Control perangkat elektronik lainnya.

Seperti dikatakan sebelumnya, LED merupakan keluarga dari Dioda yang terbuat dari Semikonduktor. Cara kerjanya pun hampir sama dengan Dioda yang memiliki dua kutub yaitu kutub Positif (P) dan Kutub Negatif (N). LED hanya akan memancarkan cahaya apabila dialiri tegangan maju (bias forward) dari Anoda menuju ke Katoda.

LED terdiri dari sebuah chip semikonduktor yang di doping sehingga menciptakan junction $\mathrm{P}$ dan N. Yang dimaksud dengan proses doping dalam semikonduktor adalah proses untuk menambahkan ketidakmurnian (impurity)pada semikonduktor yang murni sehingga menghasilkan karakteristik kelistrikan yang diinginkan. Ketika LED dialiri tegangan maju atau bias forward yaitu dari Anoda $(\mathrm{P})$ menuju ke Katoda (K), Kelebihan Elektron pada N-Type material akan berpindah ke wilayah yang kelebihan hole (lubang) yaitu wilayah yang bermuatan positif (P-Type material). Saat Elektron berjumpa dengan Hole akan melepaskan photon dan memancarkan cahaya monokromatik (satu warna).

LED atau Light Emitting Diode yang memancarkan cahaya ketika dialiri tegangan maju ini juga dapat digolongkan sebagai Transduser yang dapat mengubah Energi Listrik menjadi Energi Cahaya. Teknologi LED memiliki berbagai kelebihan seperti tidak menimbulkan panas, tahan lama, tidak mengandung bahan berbahaya seperti merkuri, dan hemat listrik serta bentuknya yang kecil ini semakin popular dalam bidang teknologi pencahayaan.

Berbagai produk yang memerlukan cahaya pun mengadopsi teknologi Light Emitting Diode (LED) ini. Berikut ini beberapa pengaplikasiannya LED dalam kehidupan sehari-hari, seperti lampu penerangan rumah, lampu penerangan jalan, papan iklan (advertising), backlight LCD (TV, display handphone, monitor) lampu dekorasi interior maupun exterior, lampu indikator, pemancar infra merah pada remote control (TV, AC, AV player).

TEKNO Vol. 29 Issue 1, p1-12 | Jurusan Teknik Elektro, Universitas Negeri Malang, Indonesia | Maret 2019

I.G.S Widharma, I.N. Sunaya | Perbandingan instalasi penerangan terhadap konsumsi daya di area line maintenance bandara ... 


\section{TEKNO Junal Teknologi Elektro dan Kejurvon}

http://journal2.um.ac.id/index.php/tekno | ISSN 1693-8739

\subsection{Komponen Yang Di Gunakan}

\subsubsection{Kabel NYM}

Digunakan untuk kabel instalasi listrik rumah atau gedung dan sistem tenaga. Kabel NYM berinti lebih dari satu ada yang berinti dua, tiga, atau empat dan memiliki lapisan isolasi PVC (Ratnata, 2011). Kabel NYM memiliki lapisan isolasi dua lapis, sehingga tingkat keamanannya lebih baik dari kabel NYA. Kabel ini dapat dipergunakan dilingkungan yang kering dan basah, namun tidak boleh ditanam.

Kode pengenal jenis kabel, yaitu:

$\mathrm{N}$ : Kabel berinti tembaga

$Y$ : Isolasi dari PVC

M : Kabel berselubung PVC (ada berinti dua, tiga, atau empat dengan isolasi PVC dua lapis)

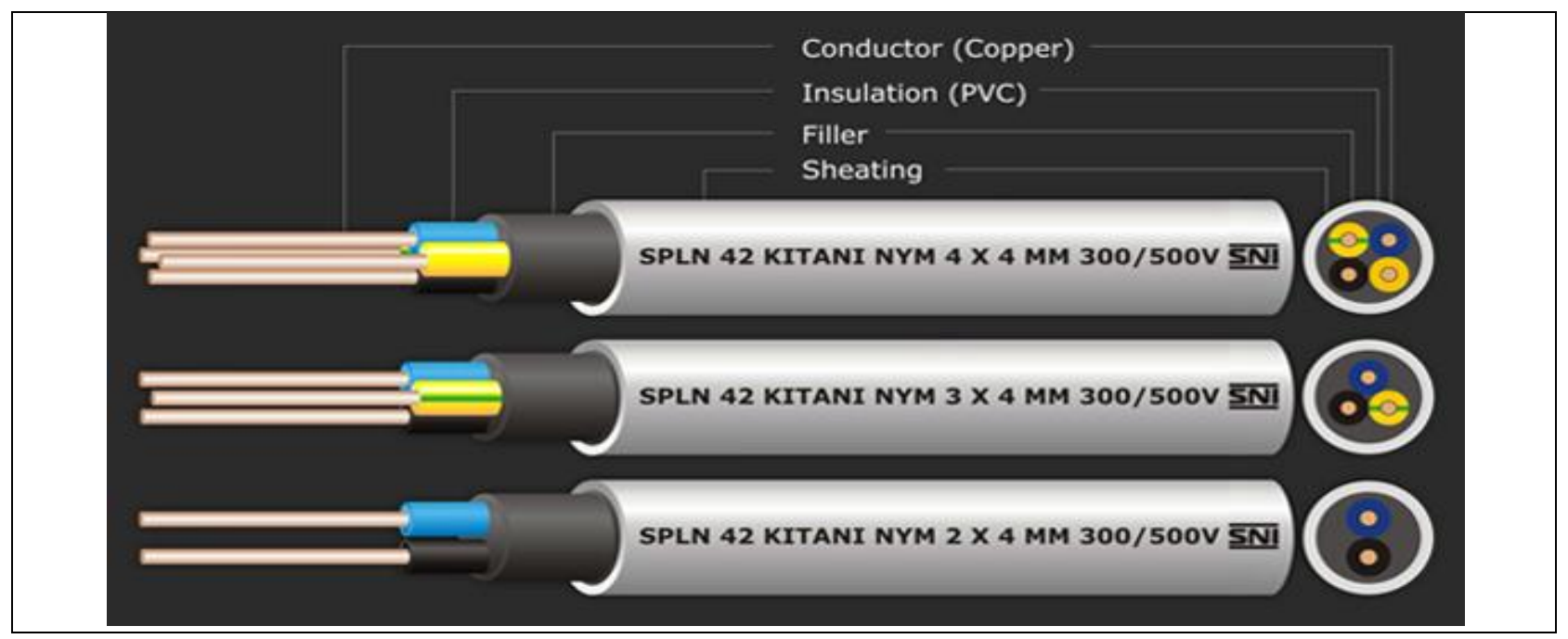

Gambar 5. Kabel NYM

\subsubsection{Lampu LED}

Lampu ini merupakan sirkuit semikonduktor yang memancarkan cahaya ketika dialiri listrik. Sifatnya berbeda dengan filamen yang harus dipijarkan (dibakar) atau lampu TL yang merupakan pijaran partikel. Lampu LED memancarkan cahaya lewat aliran listrik yang relatif tidak menghasilkan banyak panas. Karena itu lampu LED terasa dingin dipakai karena tidak menambah panas ruangan seperti lampu pijar. Lampu LED juga memiliki warna sinar yang beragam, yaitu putih, kuning, dan warna-warna lainnya. 


\section{TEKNO Jurnal Teknologi Elektro dan Kejuruan}

http://journal2.um.ac.id/index.php/tekno | ISSN 1693-8739

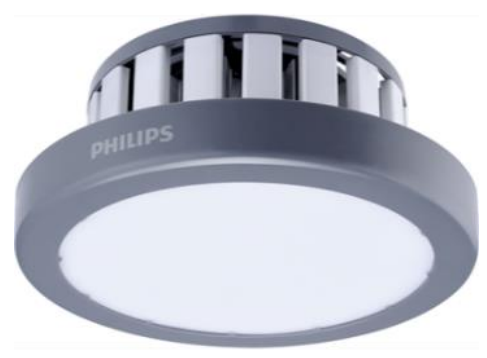

Gambar 6. Lampu LED 100 watt

\subsection{Pengaman yang Digunakan}

\subsubsection{MCB (Miniatur Circuit Breaker)}

MCB adalah suatu peralatan pemutus rangkaian listrik pada suatu sistem tenaga listrik, yang mampu untuk membuka dan menutup rangkaian listrik pada semua kondisi, termasuk arus hubung singkat, sesuai dengan ratingnya. Juga pada kondisi tegangan yang normal ataupun tidak normal.

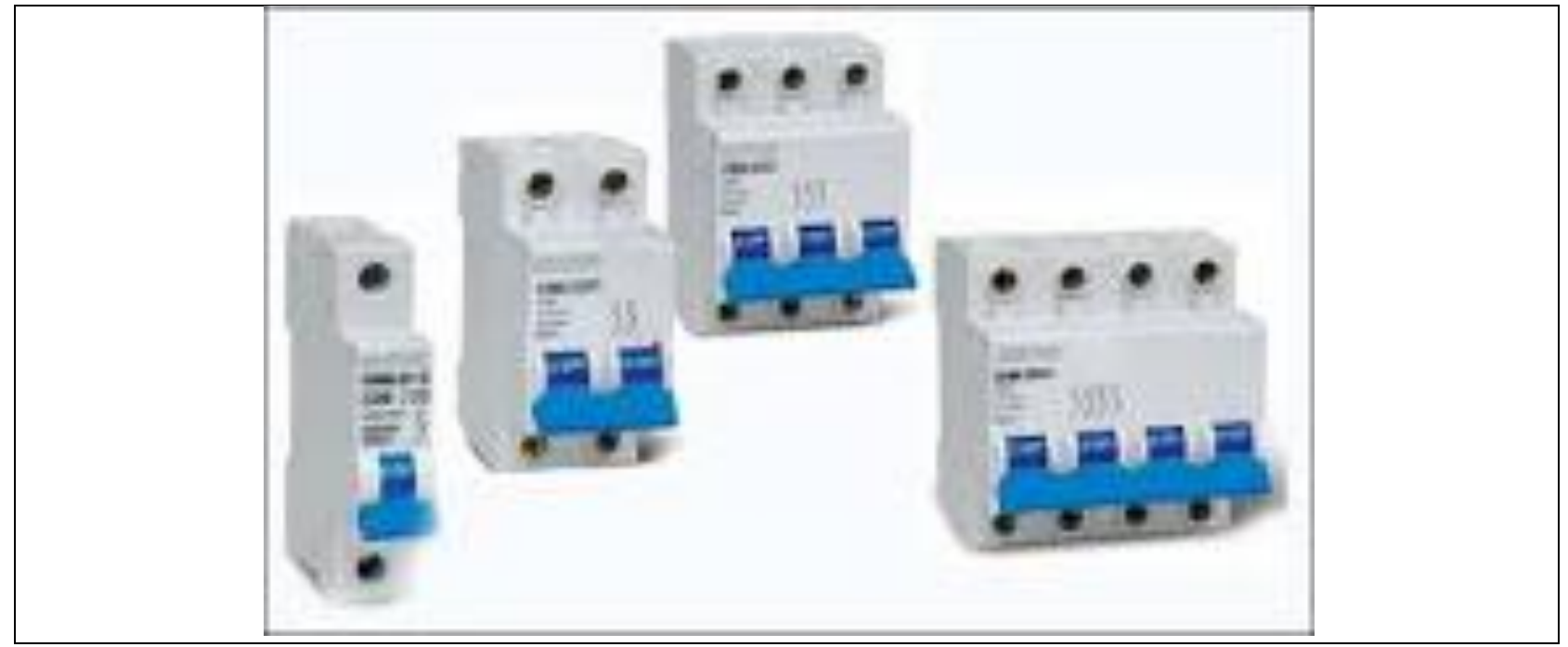

Gambar 7. MCB

Miniature Circuit Breaker (MCB) di desain dengan fungsi utama untuk mengamankan kabel terhadap beban lebih dan arus hubung singkat. melewatkan arus tanpa pemanasan lebih. membuka dan menutup sebuah sirkuit di bawah arus pengenal. 


\section{TEKNO Jumal Teknologi Elektro dan Kejuruon}

http://journal2.um.ac.id/index.php/tekno | ISSN 1693-8739

Pemilihan Miniature Circuit Breaker (MCB) atau pemutus tenaga ditentukan oleh beberapa hal, yaitu standar yang digunakan sebagai acuan.

- SPLN 108 / SLI 175, bila digunakan oleh pemakai umum (instalasi perumahan kapasitas pemutusan rendah)

- IEC 60947-2, bila digunakan oleh ahlinya (aplikasi industri - kapasitas pemutusan tinggi)

Kapasitas pemutusan suatu pemutus tenaga harus lebih besar dari arus hubung singkat pada titikinstalasi di mana pemutus tenaga tersebut dipasang. Pada diagram garis suatu sistem, disarankan untuk juga menyebutkan besar kapasitas pemutusan di samping arus pengenal pemutus tenaga yang digunakan. Arus Pengenal Arus pengenal pemutus tenaga harus disesuaikan dengan besarnya arus beban yang dilewatkan kabel dan lebih kecil dari arus yang diijinkan pada kabel.

Tegangan operasional pengenal pemutus tenaga harus lebih besar atau sama dengan tegangan sistem. Frekuensi sistem Aplikasi beban

Tipe kabel yang diamankan, tembaga atau alumunium.

\subsection{2 МССВ}

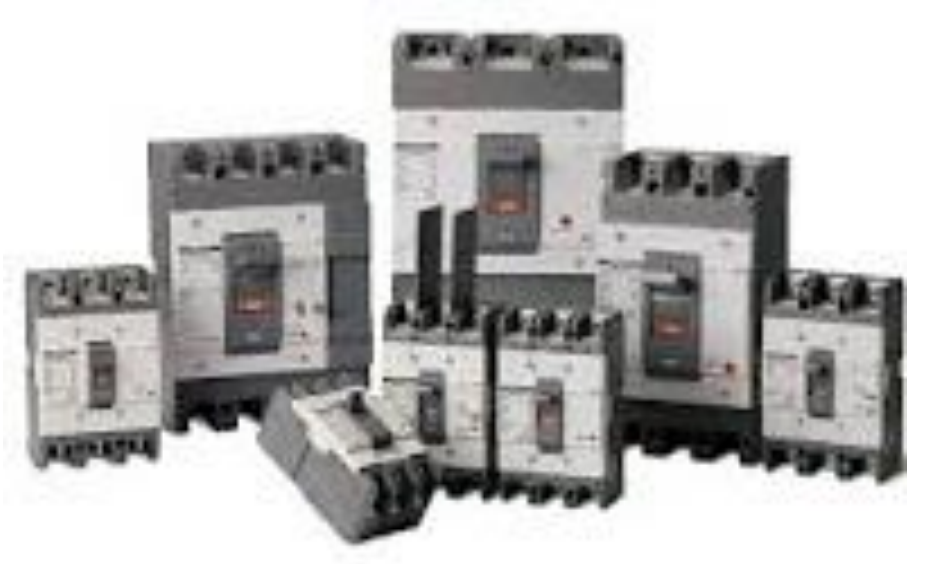

Gambar 8. MCCB

MCCB Adalah pemutus sirkuit tegangan menengah. Dalam memilih circuit breaker hal-hal yang harus dipertimbangkan adalah sebagai berikut:

- Karakteristik dari sistem di mana circuit breaker tersebut dipasang.

- Kebutuhan akan kontinuitas pelayanan sumber daya listrik.

- Aturan-aturan dan standar proteksi yang berlaku.

- Aturan-aturan dan standar proteksi 


\section{TEKNO Junal Teknologi Elektro dan Kejuruan}

http://journal2.um.ac.id/index.php/tekno | ISSN 1693-8739

- Aturan-aturan instalasi listrik yang berlaku seperti PUIL harus diperhatikan dan dituruti. Standar-standar yang diacu baik standar lokal maupun standar internasional harus diperhatikan seperti SPLN, IEC 60947-2.

\subsection{Perhitungan Daya Dan Intensitas Cahaya}

Dari data yang di peroleh kita bisa mengetahui daya dari lampu led serta pengaman yang digunakan dan menghitung intensitas penerangan rata - rata untuk mengetahui apakah intensitas penerangan di area itu sudh baik atau kurang baik. Data yang di peroleh adalah sebagai berikut :

$$
\begin{aligned}
& \Phi_{L E D}=9000 \mathrm{~lm} \\
& \text { daya led }=100 \mathrm{watt} \\
& \text { daya total }=\text { daya lampu } \times \text { jumlah total lampu } \\
& \text { daya total }=100 \times 9 \\
& \text { daya total }=900 \mathrm{watt}
\end{aligned}
$$

Sementara arus nominal ditunjukkan pada perhitungan berikut ini.

$$
\begin{aligned}
\text { I nominal }=\frac{P}{V \times \cos \varnothing} & \\
\text { In } & =\frac{900}{220 \times 0,8} \\
\text { In } & =5,1 \mathrm{~A}
\end{aligned}
$$

Sementara besarnya nilai pengaman, yaitu:

$$
\begin{aligned}
& \text { I pengaman }=125 \% \times \text { I nominal } \\
& \text { Ipengaman }=1,25 \times 5,1 \\
& \text { Ipengaman }=6,3 \mathrm{~A}
\end{aligned}
$$




\section{TEKNO Junal Teknologi Elektro dan Kejuruan}

http://journal2.um.ac.id/index.php/tekno | ISSN 1693-8739

Jadi pengaman yang digunakan adalah MCB 6A tipe $\mathrm{c}$ dengan breaking capacity 4,5 KA

Untuk menghitung besarnya intensitas penerangan rata-rata di bidang tersebut sama dengan :

$$
\text { Ep rata }- \text { rata }=\frac{\Phi_{\text {total }}}{A}
$$

Keterangan:

$$
\begin{aligned}
& \mathrm{Ep} \quad=\text { intensitas penerangan di suatu titik (lux) } \\
& \Phi \quad=\text { flux cahaya }(\mathrm{Im}) \\
& \mathrm{A} \quad=\text { luas suatu bidang atau area } \\
& \Phi_{\text {total }}=9 \times 9000 \\
& \Phi_{\text {total }}=81000 \mathrm{~lm}
\end{aligned}
$$

Luas yang dilingkupi adalah:

$$
\begin{aligned}
& A=P \times L \\
& A=15 \times 12 \\
& A=180 M^{2}
\end{aligned}
$$

Pers. (3)

Sehingga intensitas penerangan yang diperoleh:

$$
\begin{aligned}
& E \text { p rata }- \text { rata }=\frac{\Phi_{\text {total }}}{A} \\
& E p \text { rata }- \text { rata }=\frac{81000}{180} \\
& E p \text { rata }- \text { rata }=450 \mathrm{Lux}
\end{aligned}
$$

Jadi, berdasarkan hasil perhitungan diatas menunjukan intensitas penerangan rata-rata di area line maintenance Bandara Internasional Ngurah Rai Bali berdasarkan fungsi dari line 


\section{TEKNO Jurnal Teknologi Elektro dan Kejuruan}

http://journal2.um.ac.id/index.php/tekno | ISSN 1693-8739

maintenace itu sendiri sebagai tempat servis mobil bagasi di Bandara Internasional Ngurah Rai Bali, sesuai dengan tabel 3.2 hal ini termasuk dalam pekerjaan halus (pekerjaan pemasangan halus, menyetel mesin bubut otomatis, pekerjaan bubut halus, kempa halus, poles) dengan standar intensitas penerangan yang baik adalah 1000 lux (Standar Nasional Indonesia. 2000).

Berarti intensitas penerangan rata rata di area line maintenance masih kurang dari standar intensitas penerangan pada pekerjaan halus (pekerjaan pemasangan halus, menyetel mesin bubut otomatis, pekerjaan bubut halus, kempa halus, poles), karena posisi lampu di area line maintenance Bandara Internasional Ngurah Rai Bali amat sangat tinggi karena bangunnya yang tinggi.untuk mengatasi hal tersebut dalam pengerjaan yang terperinci harus menggunakan pencahayaan tambahan.

\section{Kesimpulan}

Dari pelaksanaan pemasangan instalasi penerangan di area line maintenance maka dapat disimpulkan bahwa dari perhitungan yang dilakukan, lampu LED memiliki konsumsi daya yang lebih hemat serta intensitas cahaya yang lebih baik ketimbang lampu yang lain. Sehingga pemakaian lampu LED lebih baik untuk menggantikan peran lampu bohlam. Penelitian ini dilakukan dalam penentuan jumlah lampu yang akan digunakan untuk penerangan pada instalasi lampu di Area Line Maintenance Bandara.

Saran yang dapat penulis berikan kepada pihak-pihak yang terkait dengan pekerjaan instalasi penerangan di area line maintenance ini adalah sebagai berikut,

Dalam melakukan pekerjaan, baik perawatan maupun pemasangan harus melakukan kegiatan sesuai SOP dan memakai alat pelindung diri (APD) yang sesuai dengan ketentuan.

Dalam pemasangan harus memperhatikan fungsi gedung dan jenis lampu yang akan dipasang. Jika intensitas penerangan masih kurang dari standar maka jumlah titik lampu harus ditambahkan.

\section{Daftar Rujukan}

Amaulah, H. 2002. Teknik Instalasi Tenaga Listrik. Palembang: Unsri.

Suputra Widharma IG dan Sajayasa IM. 2012. Efisiensi Konsumsi Daya Listrik di Kampus Politeknik Negeri Bali. PNB.

Standar Nasional Indonesia. 2000. Persyaratan Umum Instalasi Listrik 2000. Jakarta: Badan Standarisasi Nasional.

TEKNO Vol. 29 Issue 1, p1-12 | Jurusan Teknik Elektro, Universitas Negeri Malang, Indonesia | Maret 2019

I.G.S Widharma, I.N. Sunaya | Perbandingan instalasi penerangan terhadap konsumsi daya di area line maintenance bandara ... 


\section{TEKNO Jurnal Teknologi Elektro dan Kejuruan}

http://journal2.um.ac.id/index.php/tekno | ISSN 1693-8739

Muhaimin. 2001. Teknologi Pencahayaan. Bandung: PT. Refika Aditama.

Ratnata, I. W. 2011. Diktat Mata Kuliah Dasar-dasar Instalasi Listrik. Bandung: Tidak diterbitkan.

Suryatmo, F. 1993. Teknik Listrik Instalasi Penerangan. Jakarta: Rineka Cipta. 